\title{
Subjective symptoms after long term lead exposure in secondary lead smelting workers
}

\author{
H KIRKBY, C J NIELSEN, V K NIELSEN, AND F GYNTELBERG \\ From Medical Department C, Copenhagen University Hospital, Glostrup Division of Prospective Medicine \\ and Rigshospitalet, Occupational Health Clinic, Copenhagen, Denmark
}

ABSTRACT The prevalence of lead induced subjective symptoms was evaluated by a standardised questionnaire in a group of 96 workers employed between nine and 45 years in a secondary lead smelting works. A control group of 96 non-lead exposed subjects, matched for age and sex, were chosen from the Glostrup population study. Blood lead concentrations were in excess of 60 $\mu \mathrm{g} / 100 \mathrm{ml}$ in about $30 \%$ of the lead workers. Zinc protoporphyrin levels were found to be higher than $500 \mu \mathrm{mol} / \mathrm{Hb}$ in nearly $18 \%$ of the lead workers. The prevalence of fatigue, headache, sleep disturbance, and digestive symptoms (constipation and colic) were not higher in the lead exposed group. The body weight showed no significant difference in the two groups. Nervousness was four times more frequent in the control group. The results indicate that subjective symptoms are useless as indicators of incipient lead poisoning.

In textbooks of occupational medicine the early symptoms of lead poisoning are described as headache, tiredness, nervousness, increasing sleeplessness, loss of appetite, loss of weight, abdominal colic, and constipation. ${ }^{1-3}$ In 1977 Lilis et al studied 158 workers from two secondary smelting works and found a high prevalence of such symptoms ${ }^{4}$; in another study Irving $e t$ al also found a high prevalence of subjective symptoms among 139 lead exposed workers. ${ }^{5}$ The present study was carried out among employees in a Danish lead smelting works in an attempt to show possible long term effects of industrial lead exposure. Effects on the nervous system have been dealt with elsewhere ${ }^{6}$; here we present the prevalence of subjective symptoms possibly related to long term lead exposure.

\section{Population and methods}

\section{EXPOSURE}

The lead smelting works where our study took place is a large firm that recovers and refines metals, particularly lead from scrap storage batteries. The annual lead production rate is about 30000 tons. The crushing and smelting operations produce lead dust and lead fume and lead oxide is also encountered. Within the factory lead exposure varies to a great extent but since job rotation has always been

Received 28 April 1982

Accepted 26 August 1982 common most workers have been exposed to a similar degree. Precise individual exposures are impossible to estimate in retrospect. From air lead measurements, however, it is known that the factory had a history of high lead exposure. During the past two decades great investments have been made to decrease the exposure so that now air lead concentrations above the threshold limit value are rare.

Since 1976 blood lead concentrations have been monitored every third month on all employees. If blood lead concentrations exceed $60 \mu \mathrm{g} / 100 \mathrm{ml}$ a second measurement is made. If the second measurement is within the range $60-80 \mu \mathrm{g} / 100 \mathrm{ml}$ the employee is moved to a less lead exposed position in the factory, but if the blood level exceeds $80 \mu \mathrm{g} / 100$ $\mathrm{ml}$ the employee is sent to the local occupational health clinic.

\section{SUBJECTS}

We wished to study the effects of long term lead exposure and arbitrarily chose a period of 10 years. During 1969, however, several new workers were employed by the company, and in order to include them in the study we changed the period to nine years. All employees who had been employed on 31 December 1978 for a minimum period of nine years were invited to take part in the study. The study took place from March to September 1979 and included employees who had left the company during the study period, were receiving redundancy pay, or who had retired during this period. 
receiving redundancy pay, or who had retired during this period.

At the time of the study 265 employees were directly concerned in lead production or working in positions exposed to lead. Among these $265 \mathrm{em}$ ployees, 110 had been employed in the firm for at least nine years. Ninety-two men and four women were included in the study, giving a response rate of $88.9 \%$. Of the non-responders, two had moved abroad and 12 refused to participate for various reasons, to the best of our knowledge unrelated to their state of health.

Representatives of both the employers and employees informed us that none of the participants in the study has left the factory because of lead poisoning. According to the company few workers who have been employed for more than one year leave the job. Selection of workers for a job usually takes place within a few months of employment and the reasons for leaving are said to be non-medical. Unfortunately it has not been possible to achieve exact figures for job leaving during the nine years.

\section{PROCEDURE}

Examinations were performed in the clinic of prospective medicine, Glostrup University Hospital, and included both a general clinical health examination and a neurological examination. The health study was made in exactly the same way as a population health service study carried out one year before in the section of prospective medicine: This former population study, called the intervention investigation study (IIS), included about 1000 occupants of Glostrup aged between 30 and $60 .^{7}$

The participants received a comprehensive questionnaire including questions on subjective symptoms, own health appraisal, alcohol and tobacco consumption, social relations, sick leave, and previous use of primary and secondary health services. All participants came to the clinic after fasting overnight and were told not to smoke before the examination. After measurement of height and weight, venous blood samples were taken to determine haemoglobin, haematocrit, reticulocytes, serum alanine-aminotransferase, alkaline phosphatase, serum creatinine, blood glucose, serum cholesterol and serum triglycerides, and high density lipoprotein cholesterol. Methods of analysis have been reported elsewhere.' Blood lead concentration was determined by atomic absorption spectrophotometry ${ }^{8}$; erythrocyte zinc protoporphyrin was measured with a haematofluorimeter. ${ }^{9}$

A resting electrocardiogram, using 12 standard leads was taken, and ankle blood pressure was measured with an ultrasound device. ${ }^{10}$ All the ECGs were later read according to the Minnesota code by specially trained personnel. ${ }^{11}$ Blood pressure measurements, with the subject in the supine position and using a Hawksley Random sphygmomanometer, were taken by one nurse. ${ }^{11}$

The questionnaire which had been completed beforehand was checked by one of us and a new casual blood pressure measurement was taken; a peak flow measurement was taken with a Wright McKerro peak flow meter and a standardised physical examination was performed. After this, all the subjects had a neurological examination, the methods of which have been reported elsewhere. ${ }^{6}$ All examinations took place between 0800 and 1100.

\section{CONTROL GROUP}

For comparison with the lead smelting workers a control group of 92 men and four women was selected from the study population (IIS referred to above). The following criteria were used for selection: (1) similar age, (2) no industrial exposure to lead, and (3) same employment status as the studied group.

It was possible to fulfil the first two criteria in all subjects but 21 controls had a slightly higher employment status than the lead workers.

\section{STATISTICAL METHODS}

Statistical differences between the population group and the control group were estimated by use of a Mann Whitney or a Chi-square test. The level of significance used was $5 \%$. Correlations were estimated using a Spearman rank test.

\section{Results}

Table 1 shows the mean age, duration of employment, blood lead, and zinc-protoporphyrin values. Blood lead and zinc-protoporhyrin (ZPP) values were measured in only 22 controls since these values in Danes are well known from a recent large survey

Table 1 Age, duration of employment, blood lead concentrations, and zinc protoporphyrin concentrations in lead employees and controls

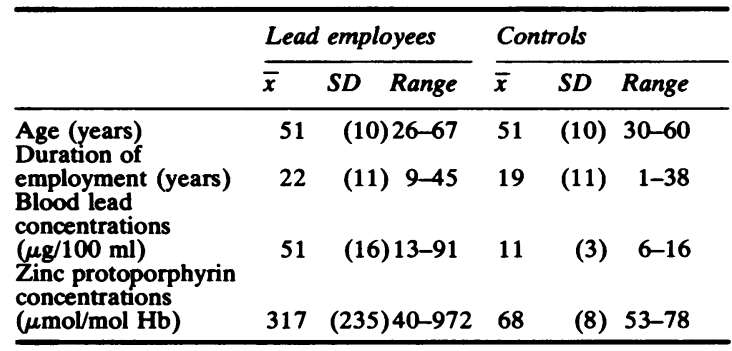


study carried out in Glostrup ${ }^{8}$ (blood lead: $13 \mu \mathrm{g}$ / $100 \mathrm{ml}$ and ZPP: $83 \mu \mathrm{mol} / \mathrm{mol} \mathrm{Hb}$ ). A highly statistically significant difference between blood lead and ZPP concentrations of the lead workers and controls was found $(p<0.00001)$. Table 2 shows the number of lead workers with different blood lead and zinc protoporphyrin concentrations. Almost $30 \%$ of the lead workers had blood lead concentrations above $60 \mu \mathrm{g} / 100 \mathrm{ml}$ which, in Denmark, is now the officially accepted upper limit for industrially exposed subjects. The corresponding biological threshold limit value for ZPP is $500 \mu \mathrm{mol}$ haemoglobin; $\mathbf{1 8 \%}$ of the lead workers had values above this level.

\section{SUBJECTIVE SYMPTOMS}

\section{Headache}

In table 3 it can be seen that the occurrence of headache was similar in the lead workers and the controls.

\section{Tiredness}

Of the 93 lead workers, $22(23.7 \%)$ gave a positive answer to a question on being often tired. In the control group 28 out of $95(29.5 \%)$ gave the same answer. This difference is insignificant. Table 4 shows the blood lead and zinc protoporphyrin concentrations in fatigued and non-fatigued lead workers; no differences can be found. Neither were there any differences in the sleeping pattern among the groups.

\section{Nervousness}

Table 5 shows answers to the question on subjective

Table 2 Blood lead concentrations and zinc protoporphyrin concentrations ( $\mu \mathrm{mol} / \mathrm{Hb})$ in lead workers

\begin{tabular}{|c|c|c|c|c|c|}
\hline \multirow{2}{*}{$\begin{array}{l}\text { Blood-lead } \\
\text { concentrations } \\
(\mu \mathrm{g} / 100 \mathrm{ml})\end{array}$} & \multicolumn{2}{|c|}{ Lead workers } & \multirow{2}{*}{$\begin{array}{l}\text { Zinc proto- } \\
\text { porphyrin } \\
\text { concentrations } \\
(\mu m o l / H b)\end{array}$} & \multicolumn{2}{|c|}{ Lead workers } \\
\hline & No & $\%$ & & No & $\%$ \\
\hline $\begin{array}{l}<40 \\
40-59 \\
60-79 \\
\geqslant 80\end{array}$ & $\begin{array}{r}25 \\
43 \\
22 \\
6\end{array}$ & $\begin{array}{r}26 \cdot 0 \\
44 \cdot 8 \\
22 \cdot 9 \\
6 \cdot 3\end{array}$ & $\begin{array}{l}<300 \\
300-499 \\
500-799 \\
\geq 800\end{array}$ & $\begin{array}{r}57 \\
21 \\
13 \\
5\end{array}$ & $\begin{array}{r}59 \cdot 4 \\
21 \cdot 9 \\
13 \cdot 5 \\
5 \cdot 2\end{array}$ \\
\hline
\end{tabular}

Table 3 Prevalence of headache in lead workers and controls

\begin{tabular}{|c|c|c|c|c|}
\hline \multirow{2}{*}{$\begin{array}{l}\text { No of times headache } \\
\text { occurred }\end{array}$} & \multicolumn{2}{|c|}{ Lead workers } & \multicolumn{2}{|c|}{ Controls } \\
\hline & No & $\%$ & No & $\%$ \\
\hline $\begin{array}{l}\text { Constantly } \\
\text { Few times a day } \\
\text { Few times a month } \\
\text { Few times a year } \\
\text { Never } \\
\text { Total }\end{array}$ & $\begin{array}{r}3 \\
8 \\
18 \\
25 \\
42 \\
96\end{array}$ & $\begin{array}{r}3 \cdot 1 \\
8 \cdot 3 \\
18 \cdot 3 \\
26 \cdot 0 \\
43 \cdot 8 \\
100 \cdot 0\end{array}$ & $\begin{array}{r}0 \\
10 \\
19 \\
27 \\
40 \\
96\end{array}$ & $\begin{array}{c}0 \\
10 \cdot 4 \\
19 \cdot 8 \\
28 \cdot 1 \\
41 \cdot 7 \\
100 \cdot 0\end{array}$ \\
\hline
\end{tabular}

Table 4 Mean blood lead concentrations and mean zinc protoporphyrin concentrations in lead workers according to reported fatigue and colic

\begin{tabular}{|c|c|c|c|c|c|c|}
\hline \multirow[t]{2}{*}{$\begin{array}{l}\text { Lead } \\
\text { workers }\end{array}$} & \multicolumn{3}{|c|}{$\begin{array}{l}\text { Blood lead concentrations } \\
(\mu \mathrm{g} / 100 \mathrm{ml})\end{array}$} & \multicolumn{3}{|c|}{ 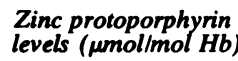 } \\
\hline & $\bar{x}$ & \pm & $S D$ & $\overline{\boldsymbol{x}}$ & \pm & $S D$ \\
\hline \multirow{4}{*}{$\begin{array}{l}\text { Fatigued } \\
(n=22) \\
\text { Not fatigued } \\
(n=71) \\
\text { Colic } \\
(n=17) \\
\text { No colic } \\
(n=78)\end{array}$} & 50 & \pm & 14 & 262 & \pm & 160 \\
\hline & 51 & \pm & 16 & 335 & \pm & 252 \\
\hline & 55 & \pm & 12 & 379 & \pm & 219 \\
\hline & 50 & \pm & 17 & 305 & \pm & 238 \\
\hline
\end{tabular}

Table 5 Prevalence of reported nervousness in lead workers and controls

\begin{tabular}{|c|c|c|c|c|}
\hline \multirow[t]{2}{*}{ Nervousness } & \multicolumn{2}{|c|}{ Lead workers } & \multicolumn{2}{|c|}{ Controls } \\
\hline & No & $\%$ & No & $\%$ \\
\hline \multirow{2}{*}{$\begin{array}{l}\text { Frequently (several times } \\
\text { a week) } \\
\text { Seldom (once or twice } \\
\text { a month) } \\
\text { Never }\end{array}$} & 3 & $3 \cdot 6$ & 16 & $17 \cdot 4$ \\
\hline & $\begin{array}{l}31 \\
50\end{array}$ & $\begin{array}{l}36.9 \\
59.5\end{array}$ & $\begin{array}{l}29 \\
47\end{array}$ & $\begin{array}{l}31.5 \\
51.1\end{array}$ \\
\hline
\end{tabular}

feeling of nervous strain. The lead workers seemed to be less nervous than the controls $(p<0.05)$.

\section{Weight loss}

The participants' own information on body weight at 20 and 30 years of age showed no difference between the controls and the lead workers. By measurement, the average weight of lead workers was found to be $78.6 \mathrm{~kg}$ as against 76.0 in the controls ( $p$ $>0.05$ ).

\section{SUBJECTIVE HEALTH EVALUATION}

The participants' health evaluation was similar in the two groups. About $9 \%$ considered their health to be extremely good, $70 \%$ good, $20 \%$ less good, and $1 \%$ poor. No differences were found in the two groups' information on absenteeism due to sickness, hospital admissions, number of operations, use of medicine, visits to casualty departments, specialist examinations, visits to dentists, and $x$ ray examinations.

\section{Abdominal discomfort}

A medical history of colic was positive in 17 of the 95 lead workers $(17.9 \%)$ and in 10 of the 94 controls $(10 \cdot 6 \%)$. This difference was not statistically significant. Table 4 shows blood lead and zinc protoporphyrin concentrations in lead workers with colic and without colic; no statistically significant differences are observed although there is a tendency for a higher zinc protoporphyrin concentration to be 
found in those with colic. Complaints about bowel movements were found in 29 of the 92 lead workers $(31.5 \%)$ and in 22 of the 95 controls $(23.2 \%)$. This difference was not statistically significant. No differences in blood lead and zinc protoporphyrin concentrations among lead workers and controls with or without complaints of bowel movements were found. No differences in symptoms of discomforts and rumblings in the stomach were observed.

\section{Discussion}

The lead smelting workers in this study have all been exposed to high levels of lead, as shown by the fact that the workers examined had blood lead and zinc protoporphyrin concentrations about five times higher than the normal population. Although some selection may have taken place in the factory because of lead exposure, this potential bias is small according to the information we had received from the company and the company doctor. For this reason the present results should be representative of symptoms found in lead exposure to the degree observed in this population. The healthy worker effect has in part been taken care of by comparing the lead smelting workers with a control group of employed subjects.

The main result of the present study of subjective lead induced symptoms is that only minor differences between lead smelting workers and an appropriate control group were found. This is in contrast with earlier studies by other authors. ${ }^{45}$ In some previous studies a higher prevalence of subjective symptoms has been observed with increased exposure to lead. ${ }^{5}$ Lead exposure in the studies cited, however, has been higher than in the workers studied in this study. Thus Lilis and co-workers found that $78 \%$ of the workers they studied had blood lead concentrations above $60 \mu \mathrm{g} / 100 \mathrm{ml} .{ }^{4} \mathrm{In}$ our study only $30 \%$ of the employees had blood lead concentrations above this level. In only one previous study of subjective symptoms in lead workers has an appropriate control group been used. ${ }^{4}$ The symptoms usually related to lead poisoning are rather vague and may be less specific than hitherto assumed. The symptoms related to lead exposure described in textbooks of occupational medicine and in some previous works have usually been described in patients with severe lead poisoning. Our results indicate that subjective symptoms are useless as indicators of incipient lead poisoning.

One possible bias in our study is that the lead smelting workers may have minimised their subjective symptoms. The workers had a positive attitude to the work and the company, which could be a reason to minimise symptoms. Despite this possible bias, we find it reasonable to conclude that blood lead and blood zinc protoporphyrin concentrations five times higher than that of the normal population are not associated with an increased prevalence of the subjective symptoms usually related to lead exposure.

\section{References}

' Zielhuis RL. Lead alloys and compounds. In: Occupational health and safety. Geneva: International Labor Office, 1976:767-71.

${ }^{2}$ Fogh A, Frost D, Jensen K. Forgiftninger. In: Thaysen D. Medicinsk kompendium. Copenhagen: Nyt Nordisk Forlag, Arnold Busck, 1980:1806-63.

${ }^{3}$ Grut A. Bly og andre forgiftninger. In: Forssman S, ed. Handbog $i$ arbejdsmedicin. Copenhagen: Munksgaard, 1976:117-21.

4 Lilis R, Pischbein A, Eisinger J, et al. Prevalence of lead disease among secondary lead smelter workers and biological indicators of lead exposure. Environmental Research 1977;14:255-85.

sIrvig LM, Roeks P, Harrison WO, Webster I. Lead and morbidity: a dose response relationship. Lancet 1978,ii:4-7.

- Nielsen CJ, Nielsen VK, Kirkby H, Gyntelberg F. Absence of peripheral neuropathy in long term lead exposed subjects. Acta Neurol Scand 1982;65:241-7.

' Agner E, Brendstrup T, Hollnagel H, Morck HI, Schroll M, Gyntelberg F. Interventionsundersøgelsen i Glostrup, 1978. Ugeskr Laeger 1979;141:3543-7.

- Olsen NB, Hollnagel H, Grandjean P. Indicators of lead exposure in an adult Danish suburban population. Dan Med Bull 1981;28:168-76.

- Grandjean P. Occupational lead exposure in Denmark: screening with the haematoffuorometer. $\mathrm{Br} J$ Ind Med 1979;36:52-8.

${ }^{10}$ Schroll M, Munck O. Estimation of peripheral arteriosclerotic disease by ankle blood pressure measurements in a population study of 60-year-old men and women. J Chronic Dis 1981;34:261-9.

"Rose GA, Blackburn H. Cardiovascular survey methods. Geneva: World Health Organisation, 1968. 